\title{
GENERAL EDITOR'S FOREWORD
}

Imperialism was more than a set of economic, political, and military phenomena. It was a complex ideology which had widespread intellectual, cultural, and technical expressions in the era of European world supremacy. The 'Studies in Imperialism' series is designed to explore, primarily but not exclusively, these relatively neglected areas. Volumes are planned on environmental aspects of imperial rule, science, education, disease, sexual opportunity, literature, art and design, among others. But in redressing the balance in favour of such multi-disciplinary and cross-cultural studies, it is not intended that the economic, political, and military dimensions should be ignored. The series seeks to demonstrate that these can only be fully understood in their wider cultural context and that imperialism had profound effects on dominant as well as on subordinate societies.

It is now recognised that juvenile literature acts as an excellent reflector of the dominant ideas of an age. The values and fantasies of adult authors are dressed up in fictional garb for youthful consumption, and the works thereby become intrumental in the dissemination and perpetuation of particular clusters of ideals, assumptions and ambitions. The period covered in this book was the first age of cheap printing and mass reading. Young readers eager for the excitements of adventure in exotic localities set up a voracious demand which authors and publishers strove to meet, both in Britain and the Empire. Business aspects of these ventures, the themes explored and the ideas conveyed, and the reception accorded to them, together with questions of race, gender and developing approaches to new technology in the twentieth century, are all covered in the chapters below. 